\title{
GENETIC DIVERSITY OF THE VP1/VP2 GENE OF CANINE PARVOVIRUS TYPE 2B AMPLIFIED FROM CLINICAL SPECIMENS IN BRAZIL
}

\author{
Cesar A. D. Pereira ${ }^{1,2}$; Edison Luiz Durigon ${ }^{1 *}$ \\ ${ }^{1}$ Instituto de Ciências Biomédicas, Universidade de São Paulo, São Paulo, SP, Brasil. \\ ${ }^{2}$ Universidade de Santo Amaro, São Paulo, SP, Brasil \\ Submitted: December 27, 1999; Approved: November 13, 2000
}

\section{SHORT COMMUNICATION}

\begin{abstract}
We evaluated the genetic diversity in the VP1/VP2 gene of CPV type $2 b$ isolates from symptomatic dogs in Brazil. A total of 21 isolates collected from 1990 through 1995 previously typed as CPV2b by PCR assay were studied. Overall we found a high degree of similarity among sequences from different CPV clinical isolates collected. Genetic analysis of this selected region gave no indication of a specific Brazilian parvovirus lineage.
\end{abstract}

Key words: genetic diversity, canine parvovirus (CPV), VP1/VP2 gene

Canine parvovirus (CPV), a new pathogen of dogs, was first isolated in 1978 in the USA (1). Analysis of CPV isolates in the USA by monoclonal antibodies and restriction enzymes have shown that after the first emergence of CPV (CPV-2) it evolved to give rise to new antigenic types, which were designated CPV type-2a and CPV type-2b $(6,8)$. The same pattern of spread of CPV-2, and the emergence and subsequent replacement by the new antigenic strains were also shown by antigenic and genetic analysis of isolates from various parts of the world, although there are various proportions of the CPV$2 \mathrm{a}$ and CPV-2b strains $(2,4,5,8-12,14)$. DNA sequence comparisons among CPV antigenic types have shown nucleotide substitutions in the VP1/VP2 capsid protein gene. Molecular structure examination of the CPV showed that most of these amino acid differences are exposed on the surface of the capsid, revealing the correlation of these residues with immunity escape, host range, and haemagglutination properties of these viruses. Some of the surface changes may also represent a further adaptation of CPV for optimal replication in an spread among dogs $(6,13)$.
In this study we evaluated the genetic diversity in the VP1/ VP2 gene of CPV type $2 b$ isolates from clinically ill dogs, in São Paulo, Brazil.

A total of 21 isolates collected from 1990 through 1995 previously typed as CPV2b by PCR assay $(3,9)$ were studied. PCR was used to amplify a 427 base region of VP1/VP2 gene and this product was sequenced. The location of the oligonucleotide primer pair, called $\mathrm{Pb}$ sense $(+)$ and $\mathrm{Pb}$ antisense $(-)$ in the CPV genome and nucleotide sequence are shown in Fig. 1.

The products of the PCR assay were electrophoresed on $1.2 \%$ agarose gel, and after DNA elution using the Concert Gel Extraction Systems (GibcoBRL), dsDNA were used as template to the sequencing reaction. The BigDye terminator-cycle sequencing ready reaction (Perkin-Elmer) was used for the sequencing reaction. Briefly, the PCR was performed in a programmed thermal cycler (Gene Amp PCR System, mod. 2400, Perkin-Elmer) for 25 cycles, each consisting of denaturation at $96^{\circ} \mathrm{C}$ for $10 \mathrm{sec}$., annealing at $50^{\circ} \mathrm{C}$ for $5 \mathrm{sec}$. and polymerization at $60^{\circ} \mathrm{C}$ for $4 \mathrm{~min}$. Following the sequencing reaction, DNA was

\footnotetext{
* Corresponding author. Mailing address: Instituto de Ciências Biomédicas, Departamento de Microbiologia, Universidade de São Paulo, Av. Prof. Lineu Prestes, 1374, Cidade Universitária, CEP 05508-900, São Paulo, SP, Brasil. Telefax (+5511) 3818-7354. E-mail: eldurigo@icb.usp.br
} 
purified according to the manufacture's instructions of the Spin Columm-Centri-Sep ${ }^{\mathrm{TM}} \mathrm{P} / \mathrm{N}$ CS-901 (Princenton Separations). The product from the previous step was then dried in a speed-vacuum for $30 \mathrm{~min}$. at $35^{\circ} \mathrm{C}$, and the pellet was suspended with $10 \mathrm{ml}$ of EDTA formamide buffer, heated for $2 \mathrm{~min}$. at $95^{\circ} \mathrm{C}$ and immediately cooled on ice until the moment to be applied in the DNA ABI Prism ${ }^{\mathrm{TM}}$ mod. 310 (Perkinm Elmer - Apllied biosystems).

The programs used for manipulation and alignment of the sequences were Sequencing Navigator, ClustalX, and Phylip.

\section{CANINE PARVOVIRUS GENOME}

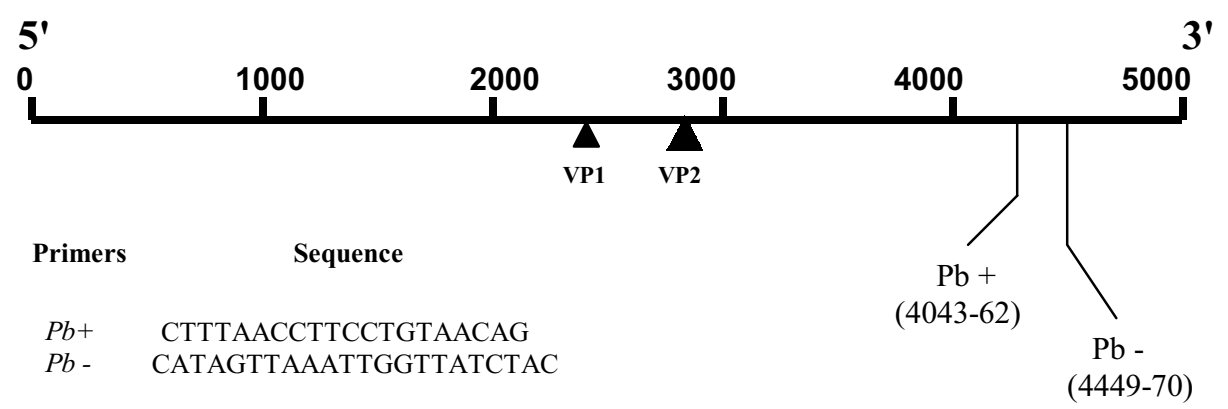

Figure 1. Nucleotide sequence and location of the primer pairs $\mathrm{Pb}+/ \mathrm{Pb}$ - in the $\mathrm{CPV}$ genome.

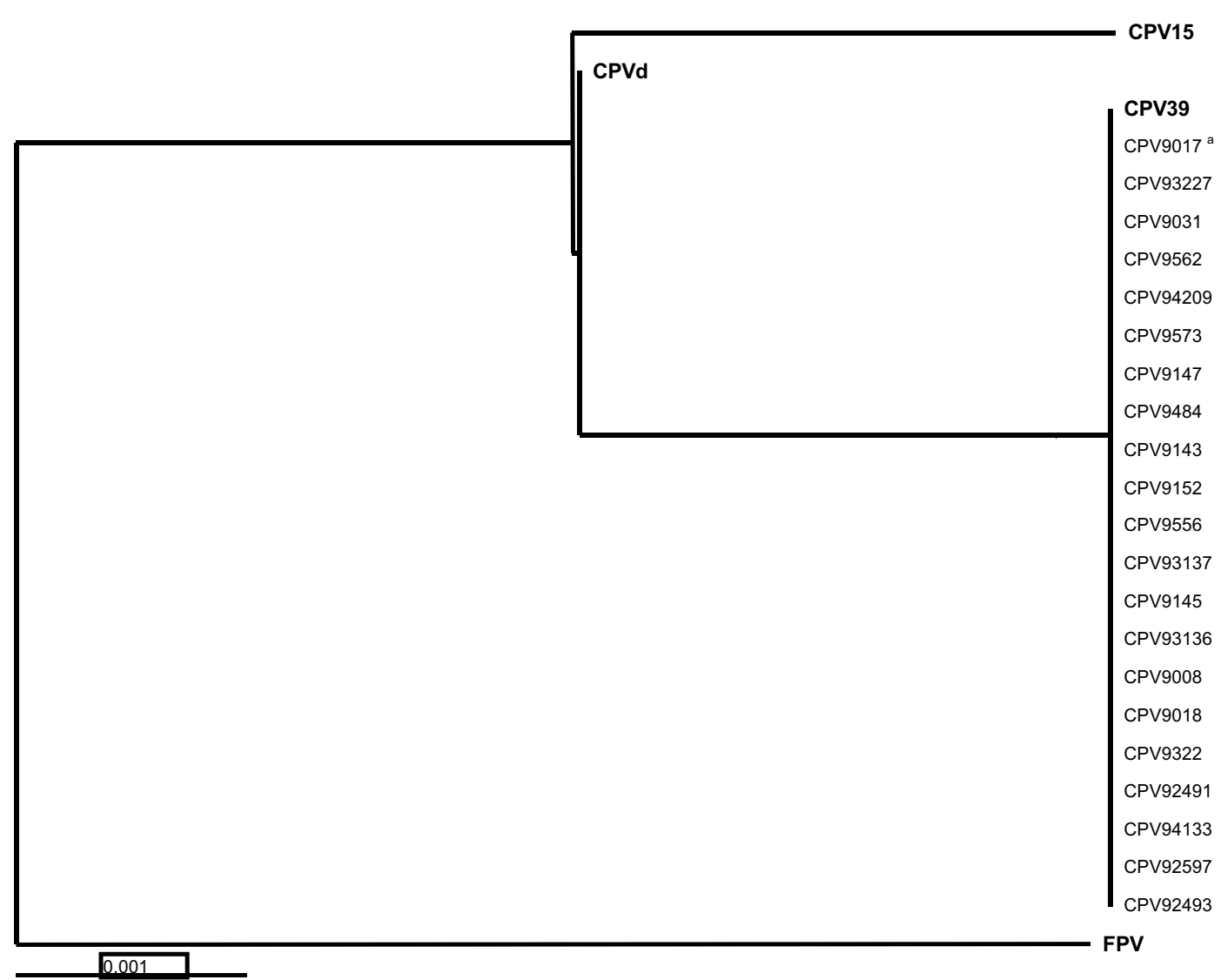

Figure 2. Distance tree for selected parvoviral coat proteins region of the CPV genome calculated by the method of Fitch. * a The numbers are our catalogue designations to the virus isolates. 
Canine (CPV-d, 15 and 39, respectively CPV types 2, 2a and $2 b$ ) and feline parvovirus sequences used as references to the alignment were obtained from the GenBank.

In this study we described the alignment of a $427 \mathrm{bp}$ fragment of the VP1/VP2 gene from $21 \mathrm{CPV}$ type $2 \mathrm{~b}$ isolates. This selected region has two of the eight nucleotide differences among CPV antigenic types that resulted in coding changes in the coat protein. The first nucleotide substitution (4062 nt) is related to the residue 426 , located at the top of the threefold spike, which is clearly involved with immunity escape and host range of the CPV. The other nucleotide change (4449 nt) is related to the residue 555 on a raise region within the two fold depression $(6,13)$.

Overall we found a high degree of similarity among sequences from different $\mathrm{CPV}$ clinical isolates collected from 1990 to 1995 . The alignment described here is in agreement with the published alignment and was also used to calculate a phylogenetic tree using the Fitch distance matrix method (Fig. 2 ). As expected, the CPV viruses cluster closely together. Genetic analysis of this selected region gave no indication of a specific Brazilian parvovirus lineage.

\section{ACKNOWLEDGMENTS}

This study was funded by FAPESP (Fundação de Amparo a Pesquisa do Estado de São Paulo, São Paulo, Brazil).

\section{RESUMO}

\section{Diversidade genética no gene VP1/VP2 do parvovirus canino tipo $2 \mathrm{~b}$ amplificado de material clínico no Brasil}

Neste estudo foi avaliada a diversidade genética no gene VP1/VP2 do parvovírus canino tipo $2 \mathrm{~b}$ a partir de amostras isoladas de cães sintomáticos no Brasil. Foram estudadas 21 amostras coletadas no período de 1990 à 1995, previamente caracterizadas como CPV $2 b$ pela técnica de PCR. Observou-se alto grau de similaridade entre as seqüências estudadas e a análise genética da região selecionada não indicou a presença de uma linhagem brasileira específica.

Palavras-chave: Brasil, diversidade genética, parvovírus canino (CPV).

\section{REFERENCES}

1. Appel, M. J. G.; Scott, F. W.; Carmichael, L. E. Isolation and immunisation studies of a canine parvo-like virus from dogs with haemorrhagic enteritis. Vet. Rec., 105: 156-159, 1979.

2. Chang, W.L.; Chang, A.C.H.; Pan, M. J. Antigenic types of canine parvoviruses prevailing in Taiwan. Vet. Rec., 138: 447, 1996.

3. Durigon, E.L.; Ângelo, M.J.O.; Jerez, J.A.; Tanaka, H.; Hagiwara, M.K. Comparação entre as reações de hemaglutinação (HA), isolamento em culturas celulares (CC), imunoeletrosmoforese (IEOF), imunomicroscopia eletrônica (IME), para o diagnóstico etiológico da parvovirose canina. Rev. Microbiol., 18: 205-210, 1987.

4. Greenwood, N.M.; Chalmers, W.S.K.; Baxendale, W.; Thompson, H. Comparation of isolates of canine parvovirus by monoclonal antibody and restriction enzyme analysis. Vet. Rec.; 138: 495-496, 1996.

5. Mochizuki, M.; Harasawa, R.; Nakatami, H. Antigenic and genomic variabilities among recently prevalent parvoviruses of canine and feline origin in Japan. Vet. Microb., 38: 1-10, 1993.

6. Parrish, C.R.; Aquadro, C.F.; Strasshein, M.L.; Evermann, J.F.; Sgro, J.Y.; Mohammed, H.O. Rapid Antigenic type Replacement and DNA Sequence Evolution of Canine Parvovirus. J. Virol., 65: 6544-6552, 1991.

7. Parrish, C. R.; Have, P.; Foreyt, W. J.; Evermann, J. F.; Senda, M.; Carmichael, L. E. The Global Spread and Replacement of Canine Parvovirus Strains. J. Gen.Virol., 69: 1111-1116, 1988

8. Parrish, C. R.; O'connell, P. H.; Evermann, J. F.; Carmichael, L. E. Natural Variation of Canine Parvovirus. Science, 230: 1046-1048, 1985.

9. Pereira, C. A. D.; Monezi, T. A.; Mehnert, D. U.; D’Angelo, M.; Durigon, E. L. Molecular characterization of canine parvovirus in Brazil by polymerase chain reaction assay. Vet. Microb., 75: 127-33, 2000.

10. Sagazio, P.; Tempesta, M.; Buonavoglia, D.; Cirone, F.; Buonavoglia, C. Antigenic characterization of canine parvovirus strains isolated in Italy. J Virol Methods., 73: 197-200, 1998.

11. Steinel, A.; Venter, E.H.; Van Vuuren, M.; Parrish, C.R.; Truyen, U. Antigenic and genetic analysis of canine parvovirus in southern Africa. Onderstepoort J Vet res., 65: 239-242, 1998.

12. Truyen, U.; Platzer, G.; Parrish, C.R. Antigenic type distribuition among canine parvoviruses in dogs and cats in Germany. Vet. Rec., 138: 365-366, 1996.

13. Tsao, J.; Chapman, M.S.; Agbandje, M.; Keller, W.; Smith, K.; Wu, H.; Luo, M.; Smith, T.J.; Rossman, M.G.; Compans, R.W.; Parrish, C.R. The Three-Dimensional Structure of Canine Parvovirus and Its Functional Implications. Science, 251: 1456-1464, 1991.

14. Ybañez, R.R.; Vela, C.; Cortéz, E.; Simarro, I.; Casal, J.I. Identification of types of canine parvovirus circulating in Spain. Vet. Rec., 136:174$175,1995$. 